\title{
KEDUDUKAN POLITIK PEREMPUAN DALAM METAFORA MASYARAKAT MINANGKABAU
}

\author{
Nurwani Idris
}

Email: nurwaniidris@yahoo.com

Fakultas Sosial dan Politik Universitas Jayabaya Jakarta

Alamat Korepondensi: Pulomas Selatan kav. 23 Jakarta Timur. Telp. (021) 4700903

\begin{abstract}
This study examines the meaning of metaphors of women in Minangkabau community, which are expressed in the form of praise to the wise and high position of women. The praise for women in the methaporic discourse does not mean the same thing in its reality. Politically, such praise for women can be a trap for women's position and freedom. Politics is closely related to the power of words, and many politicians often manipulated the words through metaphors to create political realities that are many times untrue. It is also used to change the impossibilities to be posible to attract followers. The manipulation of the metaphors are used to marginalize women in public sphere, as well.
\end{abstract}

\section{Keywords}

Metafora, Minangkabau, Perempuan

\section{Pendahuluan}

Bahasa adalah alat yang paling efektif bagi manusia dalam mengungkapkan pikiran, perasaan, sanjungan ataupun pengalaman mereka di dunia ini, apakah itu sesuatu yang terjadi dalam hubungan keseharian yang nyata ataupun pengungkapan simbol-simbol adat yang kadang-kadang merupakan suatu pandangan atau ide yang dicita-citakan atau yang diharapkan masyarakat, seperti ungkapan-ungkapan, pepatah. Di Minangkabau, kedudukan perempuan dapat diteliti dari bahasa-bahasa metafor yang berkembang di masyarakat, terutama yang terkait dengan sanjungan terhadap perempuan.

Metafora dianggap sebagai inti dari segala kegiatan yang berkaitan dengan bahasa. Menurut Muhammad Al-Fayyadl (2005:154), metafor seperti dikatakan oleh Aristoteles dalam "Poetika," pertama, bukanlah sesuatu yang murni dan intrinsik, melainkan berasal dari "sesuatu yang lain". Metafor meminjam sesuatu yang bukan hakekat dari dirinya. Dengan kata lain, metafor adalah bentuk ekspresi yang asing dan merupakan transposisi dari ekspresi dari bahasa yang lebih orisinal, yakni makna literal atau pengertian harfiah (profen) dari suatu benda. Kedua, metafor dipahami sebagai konteks gerakan (transferensi). Aristototeles menyebutnya "epiphora" yakni pemindahan istilah dari satu makna ke makna lain yang menyimpang dari pengertian aslinya, misalnya.
Kita mengatakan, "matahari merekah kala senja tiba", kita tengah menggerakkan pengertian kata "merekah" yang biasa diasosiasikan dengan "bunga", dengan sesuatu yang lain yakni "matahari" yang mempunyai makna yang berbeda. Phora adalah semacam perubahan lokasi, jadi metafo (metaphora) mendislokasi pengertian bahasa yang asli kepada pengertiannya yang menyimpang. Pergerakan metafor merupakan bentuk aktifitas bahasa (energaonta semainei) yang sering mendeviasi, membelokkan dan kadang-kadang memutarbalikkan pengertian asal dengan menciptakan logika baru, yang sama sekali berbeda dengan logika asal.

Di Minangkabau adat dan budaya yang dianut mereka adalah alam takambang jadi guru, "alam terkembang dijadikan guru". Mereka selalu mengungkapkan suatu perasaan, penilaian penghormatan, keinginan, dan sebagainya termasuk penghormatan pada perempuan terutama ibu mereka dengan ungkapan yang terdapat pada alam. Senada dengan itu Aristoteles mengatakan, "alam memerikan dirinya dalam bentuk metafor, manusia meniru pergerakan alam dan menciptakan sebuah sistem bahasa yang puitis untuk mendramatisir kekagumannya atas alam" (Al-Fayyadl, 2005:155).

Begitulah yang terjadi di Minangkabau. Adat dan masyarakat Minangkabau sangat meninggikan 
derajat perempuan. Menurut tradisi yang berlaku dan sudah mengakar kuat dalam kehidupan sosial mereka, perempuan Minangkabau dianggap sebagai sumber kearifan yang tinggi (the ultimate source of wisdom) sebagaimana cukup terkenal dalam ungkapan adatnya, perempuan adalah: (a) Amban puro; pemegang kunci harta pusaka; (b) Unduang unduang ke Madinah, payung panji ke dalam surga; dan (c) Ka-pai tampek batanyo, ka-pulang tampek babarito artinya semua keputusan yang akan diambil harus di musyawarahkan dulu dengannya.

Amban puro adalah sejenis tas yang terbuat dari kain untuk menyimpan uang atau "pura". Hampir semua orang tua perempuan di Minangkabau mempunyai puro. Ini artinya, "Perempuan adalah pemelihara kesejahteraan rumah tangga" dan pemahaman ini telah menjadi suatu tradisi yang mengakar dalam kehidupan sehari-hari. "Pelindung ke Madinah", maksudnya pengantar ke Tanah Suci, dan "payung panji ke dalam surga" artinya "sebelum pergi tempat bertanya dan ketika sudah pulang tempat berberita atau memberitahukan". Dalam konteks ini, otoritas relatif berada di tangan perempuan tua (ibu dan nenek) yang bertindak sebagai pengontrol kekuasaan. Dalam keluarga Minangkabau, leluhur perempuan yang paling tua, jika masih hidup, sebenarnya mempunyai kedudukan yang lebih tinggi dibanding mamak, karena -menurut Willinck- perempuanlah yang memegang harta pusaka, sebagai pemegang tanggung jawab ekonomi tertinggi dan sekaligus sebagai pengontrol kekuasaan di nagari (Tanner, 1967:2). Konsekuensinya, seperti pendapat Ok-Kyang Pak dan Prindiville, tidak ada keputusan penting yang dijalankan tanpa sepengetahuannya (Tanner, 1967:4).

Sistem matril ini menggambarkan pola budaya egaliter. Menurut alam pikiran Minangkabau, egaliti berarti persamaan atau kesetaraan yang menunjukkan bahwa baik laki-laki maupun perempuan mempunyai kedudukan sama, duduk sama rendah dan tegak sama tinggi (Navis, 1999:60). Mereka menempatkan perempuan Minangkabau dalam posisi sentral dan mantap dalam masyarakatnya dan sederajat, bahkan lebih tinggi daripada laki-laki.

\section{Metode}

Merujuk pada beberapa kerangka berfikir diatas, akan dikaji hubungan antara makna kata dari metafora terhadap perempuan dengan kebebasan perempuan tersebut apakah metafora itu merupakan kebebasan atau perangkap bagi mereka untuk memasuki dunia politik.
Secara obyektif, penelitian ini dilakukan dengan beberapa pertimbangan. Pertama, fenomena bahasa yang dipakai dalam metafora dalam penyanjungan terhadap perempuan Minangkabau memiliki karakteristik yang unik dalam menyingkap begitu tingginya posisi perempuannya dalam adat, tetapi mereka tetap termajinal dalam politik. Kedua, metafora yang melambangkan kedudukan mereka itu sesuai dengan pandangan hidup yang mereka anut yakni "alam takambang jadikan guru" dan didasarkan pada "adat bersendi syarak, syarak bersendi kitabullah" yang menjadi tuntunan moral dalam kehidupan mereka sampai sekarang. Ketiga, belum ada penelitian yang menelaah secara khusus makna kata metafora terhadap kebebasan perempuan Minangkabau dalam politik.

Ditinjau dari perspektif pemaknaan kata, tidak ada makna yang stabil dalam teks. Sebuah teks selalu ditandai oleh perubahan terus menerus dan tidak mungkin ditetapkan dalam penafsiran yang tunggal. Oleh sebab itu tulisan ini memakai metode "Dekonstruksi", yakni salah satu bentuk strategi literer terhadap teks-teks filsafat. Menurut Barbara Johnson (2004: xiv) bahwa: pengertian dekonstruksi adalah lebih kepada analisis; mengurai; melepaskan; membuka (to undo) ketimbang pengertian "destruksi" dan menurut Webster's Unabridged Dictionary pengertian analisis sebagai "the separating of any material or abstract entity into its constituent elements", yang berarti "to break down into constituent parts". Tujuannya adalah untuk mengungkap oposisi-oposisi yang implisit dalam teks oleh karena itu jika sebuah teks di dekonstruksi, yang dihancurkan bukanlah makna tetapi klaim bahwa satu bentuk pemaknaan terhadap teks lebih benar ketimbang pemaknaan lain yang berbeda.

Penelitian ini bersifat kualitatif sesuai dengan pendapat Lincoln dan Denzin (1994:576), yaitu mencakup dua ketegangan sekaligus pada waktu yang bersamaan. Maksudnya, di satu sisi ia menggambarkan secara luas aliran interpretive, postmodern, feminis dan kritikal yang amat peka, namun di sisi lainnya ia juga menggambarkan bagian yang lebih banyak dari aliran positivisme, postpositivisme dan konsepsi naturalistik dari pengalaman manusia dalam setiap analisisnya, dalam hal ini masyarakat dan perempuan Minangkabau.

Oleh sebab itu, pendekatan yang dipakai disini ialah pendekatan "verstehen" (pemahaman dari sudut subjek penelitian) dan interpretatif hermeneutik (penafsiran simbol-simbol kultural). Dengan menyadari bahwa tidak mungkin kita 
mengumpulkan semua data statistik yang diperlukan untuk melakukan analisa kuantatif dan terukur, penelitian ini lebih memusatkan perhatian pada pemahaman fenomena tersebut secara rasional dan mempergunakan akal sehat (common sense) dengan cara mendasarkan informasi pada berbagai sumber.

Analisis data dilakukan secara langsung dengan menganalisa makna atas simbol-simbol yang terdapat dalam jawaban yang diperoleh dari para tokoh bersangkutan, karena para tokoh terutama niniak mamak selalu berpepatah petitih, dengan menggunakan cara yang diberikan oleh Derrida. Dalam proses penciptaan makna, Derrida mendudukkan teks bukan lagi dalam posisi sentral, teks yang sudah mapan dan presence perlu didekonstruksi. Dekonstruksi berfungsi ganda yaitu: a) sebagai cara membaca teks sedemikian rupa, dengan cara berpikir secara terusmenerus sampai didapatkan landasan yang tidak terbantahkan lagi (indisputable); b) menolak makna harafiah atau self-indentical dari teks karena teks mempunyai keterbatasan dan perlu dikonstruksi dengan hermeneutik, terutama teks politik dan agama dalam jawaban niniak mamak seperti "setuju berpolitik", namun harus selalu berpegang teguh pada adat bersendi syarak, syarak bersendi Kitabullah.

Penelitian dilakukan di Kota Padang, ibukota Provinsi Sumatera Barat, ibukota Kabupaten Tanah Datar, Kabupaten Agam, dan Kabupaten Lima Puluh Kota. Ketiga kabupaten ini dikenal dalam tradisi sebagai "Luhak nan Tigo", yaitu The Heartland of Minangkabau. Yang juga akan diteliti adalah tokoh Nagari dari ketiga kabupaten tersebut, termasuk Nagari Pangkalan Kota Baru, Kabupaten Lima Puluh Kota, Nagari Kamang di Kabupaten Agam, dan Nagari Sungayang di Kabupaten Tanah Datar. (Nurwani, 2007:28-39).

\section{Kedudukan Perempuan dalam Masyarakat Minangkabau}

Minangkabau mempunyai sistem sosial masyarakat dengan karakteristik yang unik dari masyarakat Sumatera Barat, yang mungkin dapat dikatakan paling mencolok, adalah keserasian antara salah satu sistem matrilineal yang kuat yang masih ada dan keyakinan yang teguh terhadap Islam pada sebagian besar masyarakat Minangkabau.

Dulu sewaktu nilai-nilai budaya yang membentuk pribadi dan masyarakat Minangkabau masih terbatas kepada nilai-nilai adat dan agama, kedudukan perempuan Minangkabau dalam gambaran stereotipnya, adalah kukuh, kuat dan anggun. Perempuan Minangkabau dilambangkan dengan predikat "Bundo Kanduang" yang berarti matriarkat. Dia adalah figur sentral dalam keluarga. Dia merupakan pusat jala dari keseluruhan sistem dalam keluarga. Semua persoalan dalam keluarga dinisbatkan kepadanya, dan dia adalah penentu kebijaksanaan dalam keluarga dan pengontrol kekuasaan. Karena itu, apapun keputusan yang akan diambil, yang menyangkut keluarga ataupun suku selalu dimusyawarahkan dulu dengannya. Tidak ada keputusan yang diambil tanpa sepengetahuannya.

Bundo Kanduang sesuai dengan fungsinya dipersonifikasikan sebagai tetua dalam keluarga yang mempunyai sifat arif bijaksana, yang artinya adalah seorang perempuan yang sudah matang, kuat kepribadiannya dan memiliki kearifan, dan berada dalam puncak kehidupannya. Bundo Kanduang dalam artian ideal-abstrak-filosofisnya pada hakikatnya adalah nilai-nilai ideal kewanitaan Minangkabau itu sendiri. Setiap perempuan Minangkabau dalam bersikap dan berperilaku berusaha menyesuaikan diri dan mentaatinya. Bundo Kanduang, dalam artian ideal-abstrak-filosofis, adalah perlambang dan sekaligus personifikasi dari kebudayaan Minangkabau itu sendiri yang ciri khasnya adalah matrilineal. Hal ini dilambangkan dengan limpapeh rumah nan gadang, tiang (tonggak rumah besar), penguasa pemegang kunci harta pusaka. Amban puro, unduang unduang ke Madinah, payung panji ke dalam surga, ka-pai tampek batanyo, ka-pulang tampek babarito (Naim, 1991).

Simbol sebagai limpapeh rumah nan gadang, bermakna perempuan Minangkabau yang berperan sebagai: (a) pendidik yang sangat besar artinya bagi masyarakat Minangkabau; "limpapeh rumah nan gadang" melambangkan perempuan sebagai tiang rumah gadang yang berkewajiban untuk memperhatikan pendidikan, moral, budi pekerti anak-anaknya agar menjadi orang yang berguna dan bertanggung jawab bagi keluarga, kaum dan sukunya serta bangsanya, jika tidak rumah gadang ini akan runtuh; (b) sebagai pengelola keuangan rumah tangga, dimana uang berada di tangannya; "amban puro" penguasa pemegang kunci harta pusaka; (c) sumber kearifan sebagai tempat bertanya, karena wibawa, pendidikan yang dipunyainya; (d) pembimbing etika moral agama, untuk jalan ke sorga, namun dia bukanlah politikus yang menyebabkan mereka menganggap politik bukanlah dunia mereka, namun mempunyai kekuasaan politik yang kuat dalam masyarakatnya sebagai pengontrol kekuasaan, karena yang melaksanakan public policy adalah 
laki-laki, dapat dikatakan perempuan adalah penentu dan laki-laki adalah pelaksana

\section{Makna Sikap Politik Minangkabau Menurut Adat}

Setiap masyarakat mewariskan pranata sosial yang dibangun dari generasi ke generasi dalam suatu proses sosialisasi. Dalam proses sosialisasi ini, makna dan nilai dari pranata sosial masyarakat Minangkabau tersebut diwariskan sedemikian rupa sehingga setiap individu terstruktur dalam kesadaran yang kuat dalam suatu konstruksi sosial yang berfungsi sebagai "legitimasi" dalam praksis sosialnya.

Pranata sosial di Minangkabau didasarkan pada falsafah alam takambang jadi guru (alam terkembang jadikan guru) yang berlandaskan adat bersendi syarak, syarak bersendi kitabullah, yang menjadi pegangan hidup dan way of life masyarakat Minangkabau yang sangat menghargai kaum perempuannya sehingga kedudukannya sangat sentral. Sebelum dijajah Belanda, walaupun tidak duduk dalam struktur politik secara formal, namun perempuan adalah pengontrol kekuasaan, bahkan menurut legenda ada perempuan Minangkabau yang menjadi raja. Namun, akibat proses marginalisasi yang terjadi selama berabad-abad, kedudukan perempuan Mingakabau sebagai pengontrol kekuasaan secara formal menjadi hilang. Meski demikian, posisi pengontrol dalam lingkup yang lebih sempit atau non-formal, masih tetap terjaga seperti dalam keluarga, kekerabatan dan suku yang sampai sekarang masyarakat Minangkabau sangat menghormati perempuan terutama ibunya.

Dengan demikian yang terjadi adalah segala urusan yang menyangkut urusan publik, diurus dan ditangani oleh laki-laki atau mamak, yakni penghulu, dijalankan atas kontrol perempuan yang disebut Bundo Kanduang. Kekuasaan dijalankan dengan falsafah "alam takambang jadi guru" (alam terkembang jadikan guru) untuk mencapai dan menjaga harmoni, serta didasarkan kepada "adat bersendi syarak, syarak bersendi kitabullah" yang artinya adalah urusan publik atau politik dijalankan berdasarkan ketentuan atau norma yang telah ditentukan oleh adatdan berdasarkan pada agama. Dengan kata lain, tindakan apapun yang akan diambil termasuk tindakan politik atau publik selalu didasarkan pada konsep tersebut. Konsep agama ini sudah menjadi prinsip dasar dari politik kerajaan Melayu, termasuk Minangkabau yang mengambil ajaran Taaj al-Salathin yang mengharuskan seorang penguasa harus berlaku adil dan selalu mengingat ajaran agama bahwa penguasa yang dzalim akan mendapat hukuman. Konsep politik ini juga berpegang pada prinsip alam takambang jadi guru (alam terkembang jadikan guru) dan berdasarkan adat bersendi syarak, syarak bersendi kitabullah.

Untuk menafsirkan makna teks di atas, diperlukan penafsiran hermeneutika, yakni studi pemahaman makna teks uraian terhadap kesan manusia. Dengan asumsi bahwa makna dari sebuah teks tersusun dalam satu kesatuan dengan budaya yang mewadahinya. Dengan demikian, penafsiran makna teks tersebut harus mengacu pada konteks situasi sosial dan konteks budaya sebagai latar belakang lahirnya kata yang mewadahi, memberi makna, atau nilai pada lahirnya teks itu. Bertalian dengan asumsi itu, interaksionisme simbolik digunakan pula sebagai perspektif teoretis dan orientasi metodologis dalam penelitian ini karena dimensi paling penting yang menjadi fokus perhatiannya adalah menggali dan menemukan makna dibalik yang sensual. Dan alasan lain adalah salah satu gagasan yang dimunculkan adalah "perilaku dan interaksi manusia dapat dibedakan karena adanya simbol yang bermakna". (Bustan dan Ola dalam Humaniora, 2010:154; Muhajir, 1998:135; Palmer, 2003:9; Bungin, 2007:181-185).

\section{Makna Metafora tentang Perempuan Minangkabau}

Makna metafora ini, berkaitan erat dengan struktur masyarakat Minangkabau seperti dikatakan Lechte (2000:15 dalam Averroes, 2008) bahwa ada yang dilupakan dalam suatu wacana yakni mengenai fenomena struktural yang terdapat dalam relasi perbedaan suatu masyarakat. Oleh karena itu, sejarah ilmu bukan ungkapan pikiran melainkan suatu konfigurasi epistemologis. Struktur adalah kesatuan beberapa unsur atau elemen yang terdapat dalam relasi yang sama pada "aktivitas" manusia. Kesatuan struktur tersebut tidak bisa dipilah secara terpisah menjadi elemen karena struktur adalah subtansi dari hubungan antar elemen.

Seperti uraian di atas, adat Minangkabau sangat meninggikan derajat perempuan dalam berbagai metafora seperti: "Dia adalah limpapeh rumah nan gadang, amban puro, unduang-unduang ke Madinah, pai tampek batanyo, pulang tampek babarito", sementara sebagai limpapeh rumah nan gadang, ia harus selalu berada di rumah, sebagai penerus keturunan, penjaga harta pusaka, dia harus selalu dilindungi, pekerjaan yang keras tidak cocok bagi mereka dan mereka juga pengontrol kekuasaan, namun kekuasaan yang dipunyainya adalah bersifat informal, sehingga menjadikan mereka tidak terbiasa dengan urusan publik. 
Realitas dari makna yang terkandung dalam metafora ini terkonstruksi dalam frame atau pembingkaian alua dan patuik (alur dan patut) yang menjadi dasar mufakat Minangkabau, tenggang rasa dalam berperilaku sudah diwariskan turun temurun; "yang didasarkan pula pada budi dan sangko" Elok di awak, lamak dek urang (pantas untuk kita, enak juga bagi orang lain). Hak dan kewajiban individunya ditentukan oleh tingkat organisasi sosial. Sebagai anggota keluarga, ia diharapkan untuk mempertahankan tingkat organisasi sosial terendah ini.

Dalam hubungan antar suku, ia harus membela kepentingan sukunya. Dalam hubungan antar nagari, ia harus menjadi kampiun nagarinya. Makin tinggi tingkat organisasi sosial, makin sedikit haknya dan makin berat tanggung jawabnya. Eksistensi suatu nagari adalah dunia kecil dalam konteks alam Minangkabau tergantung pada sukunya, yang pada akhirnya dibentuk oleh kumpulan keluarga matrilineal. Dengan demikian, eksistensi ini menyebabkan besarnya beban kurtural yang ditanggung mereka menjadi bertambah berat (Abdullah, 1987:15).

Frame atau pembingkaian alur dan patut oleh masyarakat, niniak mamak, alim ulama atau partai politik atau pemerintah daerah, bisa saja menjadi perangkap bagi perempuan Minangkabau yang menghegemoninya dengan ajaran dan makna alur dan patut tersebut. Ajaran ini dengan sendirinya bisa mengikat mereka di ranah domestik.

Konstruksi sosial atau wacana sosial ini telah menjadi suatu perdebatan seperti dikatakan Derrida bahwa makna diberikan oleh simbol verbal dan setiap pelakunya akan melakukannya dengan cara yang berbeda (Rusbiantoro, 2001:15). Simbol verbal tersebut adalah penggunaan bahasa. Dengan bahasa segala sesuatu dapat dikendalikan oleh penguasa atau elit politik. Orang yang mempunyai kekuasaan dapat memberikan suatu konsep, mendefinisikannya dengan apa yang dapat dikatakan dan apa yang dapat didiamkan, sehingga membatasi realitas sosial perempuan tersebut. Jadi, wacana di atas akan menjadi perangkap bagi kebebasan perempuan itu sendiri. Masih menurut Derrida, teks adalah realitas kehidupan manusia, setiap tindakan berbicara manusia bisa diartikan dengan dua cara. Pertama, konstantif, yakni pernyataan fakta seperti apa adanya; kedua, performatif, yakni pernyataan yang tidak hanya kata-kata tapi diikuti dengan tindakan (Wattimena, 2009).
Sehubungan dengan itu, Gramsci (2000) mengatakan bahwa struktur pemikiran seharihari mengenai "konsep segala sesuatu" di dalamnya terdapat bermacam aturan dan kekuasaan yang tersembunyi; apa yang dianggap pasti atau sudah jelas, sebenarnya di dalamnya tersembunyi legitimasi kekuasaan atau aktivitas sosial lainnya. Mereka yang memegang kekuasaan tidak perlu menjelaskan sesuatu, karena segala sesuatu itu memang telah begitu adanya. Jika ada keinginan untuk mengubah sesuatu itu dalam masyarakat, harus ada keinginan atau usaha untuk itu, yakni mengubah struktur dan muatan pemikiran serta citra yang terkait dengan konsep yang bersangkutan.

Senada dengan persoalan di atas Erving Goffman (dalam Hiilamo dan Kangas, 2005:8-10) menyatakan, "Dalam keadaan apa kita menganggap segala sesuatu itu nyata". Menurut Goffman, menginterpretasikan segala sesuatu itu "ada"; "benar"; atau "nyata" bergantung pada frame atau bingkai, di mana segala sesuatu itu diinterpretasikan. Pada dasarnya menurut Goffman, ide ini seperti cara kuno yang kita ketahui dari psikologi gestalt: dua garis yang panjangnya sama diletakkan dalam bingkai berbeda yang dibentuk oleh anak panah yang mengarah ke dalam atau ke luar sehingga membentuk garis tersebut terlihat berbeda panjangnya.

Oleh karena itu, partai politik juga dapat mencoba menggunakan bingkai ini dengan sedikit berbeda. Mereka mencoba menjadikan solusi yang berbeda tapi terlihat sama. Dengan mengacu pada nilai budaya yang diterima luas seperti kebebasan, keadilan, dan kesetaraan sosial, mereka mencoba mengajukan alternatif kebijakan mereka sendiri. Yakni, mengemas solusi berbasis kepentingan mereka sendiri dalam bingkai yang diterima secara umum partai 'mencuci' preferensi mereka.

Faktor tersebut di atas bisa mempengaruhi tindakan para pelaku politik dalam usaha mereka untuk meraih kepemimpinan politik atau yang umum dikenal sebagai partisipasi politik secara aktif atau aktualisasi diri dalam arena politik, dan sebagai alat untuk menyingkirkan lawan-lawan politiknya termasuk perempuan Hal ini dilandasi oleh konstruksi sosial para pelaku politik itu sendiri, dari sikap dan pandangan mereka terhadap politik, dengan alasan bahwa perempuan tempatnya di rumah sebagai penjaga harta pusaka, urusan luar dan urusan publik senantiasa diurus oleh laki-laki, dipandang dari konsep politik dan azas demokrasi, pada akhirnya makna kata dari metafora yang 
menjunjung tinggi perempuan dapat menghambat kebebasan perempuan itu sendiri.

Sehubungan dengan persoalan ini, Berger (1991:17) mengatakan bahwa ada tiga momen dialektis yang terjadi yang mendasari konstruksi sosial dalam masyarakat, yaitu eksternalisasi, objektivikasi, dan internalisasi. Melalui eksternalisasi, manusia mengekspresikan diri membangun dunianya. Ekspresi ini memanifestasikan suatu realitas objektif setelah melalui proses objektivikasi. Dalam hal di atas, karena urusan publik adalah urusan laki-laki, maka perempuan Minangkabau berpandangan: "politik bukanlah urusannya". Demikian pula realitas objektif yang juga akan berpengaruh kuat bagi pembentukan perilaku manusia termasuk perilaku politik setelah ia melewati tahap internalisasi yang tahap ini memerlukan legitimasi.

Fungsi legitimasi menurut Sastraprateja (Pengantar dalam Berger, 1991:xvi), adalah kognitif dan sekaligus normatif. Kognitif menjelaskan makna realitas sosial dan normatif karena akan memberi pedoman bagaimana seseorang harus berlaku dalam kehidupan riil. Menurut Berger, agama merupakan bentuk legitimasi paling efektif karena agama yang paling komprehensif membicarakan tentang realitas seperti tragedi, penderitaan, serta ketidakadilan ketika agama menjadi seperangkat legitimasi dalam interaksi sosial

Objektivasi masyarakat dalam politik mencakup semua unsur pembentuknya, yakni pranata sosial termasuk lembaga, peran, identitas yang bersifat nyata secara objektif. menurut Berger, masyarakat kini berfungsi sebagai pelaku formatif bagi kesadaran individu, yang telah terinternalisasi sehingga individu memahami berbagai unsur realita sosial yang terobjektivasi sebagai fenomena yang internal dan berpengaruh terhadap kesadarannya secara bersamaan ketika dia memahami unsur itu sebagai fenomena realitas internalnya, seperti apa yang telah dialami oleh perempuan Minangkabau bahwa politik itu bukan dunia perempuan telah mempengaruhi minat dan kesadaran politiknya, yang kemudian mempengaruhi aktualisasi politiknya yang telah memerangkapnya di ruang domestik dan akan sulit bagi mereka keluar dari perangkap itu.

Pada akhirnya, objektivasi aktivitas manusia berarti bahwa manusia menjadi mampu mengobjektivasikan bagian dari dirinya di dalam kesadarannya sendiri. Dengan kata lain, manusia mengaktualisasikannya dalam setiap sikap dan motif dari tindakannya tersebut yang biasanya menjadi unsur objektif dalam realita. Dengan demikian, partisipasi politik perempuan akan tergantung pada bagaimana sikap dan pandangannya terhadap politik yang terkonstruksi secara sosial dan pada akhirnya akan mempengaruhi minat politiknya. Hal ini diimplementasikan dengan tindakan mengaktualisasikan diri dalam kehidupan secara penuh yang jauh dari kebebasan. Dengan kata lain perempuan tidak mempunyai kebebasan penuh dalam politik serta partai politik sebagai "gate keeper" bisa saja menghambat partisipasi mereka dengan pembingkaian makna alur dan patut serta adat bersendi syarak syarak bersendi kitabullah yang kesemuanya itu menghasilkan perangkap domestik.

Keberhasilan sosialisasi yang telah terinternalisasi tergantung pada adanya simetri antara dunia objektif masyarakat dengan dunia subjektif individu. Jika kita membayangkan seorang individu yang tersosialisasi secara total, maka setiap makna yang secara objektif terdapat dalam realita sosial yakni sanjungan-sanjungan dalam metafora tersebut akan bermakna secara subyektif di dalam kesadaran individu itu sendiri. Sosialisasi total seperti itu secara empiris tidak akan ada dan secara teoretis tidak mungkin ada, jika hanya didasarkan pada keadaan biologis individu. Sosialisasi total mungkin akan terealisasi kalau ada pengaruh faktor-faktor sosial lainnya, seperti faktor-faktor yang telah diuraikan pada point-point diatas. Dapat juga dijelaskan dengan konsep Derrida (Al-Fayyadl, 2005:78) dimana perlu memberdayakan pemaknaan yang tersirat karena penampakan sebuah teks tidak sedatar penampang permukaanya seperti di Minangkabau, limpapeh rumah nan gadang (tiang rumah besar, amban pura, alur dan patut, budi dan sangko) yang selalu harus menjadi pertimbangan dalam bersikap, dengan kata lain telah mendominasi setiap langkah yang akan diambil.

Jika sosialisasi itu tidak berhasil menginternalisasi makna yang paling penting dari suatu masyarakat politik tertentu, maka masyarakat tersebut menjadi sulit untuk mencapai tingkat aktualisasi tanpa suatu usaha yang berkesinambungan.

Secara khusus, masyarakat semacam itu yakni masyarakat Minangkabau dan perempuannya tidak akan mampu membentuk suatu tradisi yang akan menjamin kelestarian masyarakat politik itu sendiri (Berger, 1991:19-22), karena simbol verbal, dan pembingkaian makna alur dan patut, yang didasarkan pada adat bersendi syarak bersendi kitabullah telah terinternalisasi yang telah menjadi bagian dari way of life masyarakat 
Minangkabau, dengan kata lain dia telah terinstitusionalinasi dalam lembaga kehidupan kemasyarakatan di Minangkabau dapat juga dijelaskan dengan konsep Foucault yang mengatakan bahwa: "ada kekuasaan yang tersentralisasi dalam institusi dan wacana ilmiah yang tertata dalam masyarakat" (Foucault, 2002:104). Selanjutnya mengatakan bahwa kekuasaan sama luasnya dengan lembaga sosial, tidak ada ruang yang bebas dari jaringannya, relasi kekuasaan saling terjalin dengan jenis relasi lain seperti produksi, kekerabatan, dan keluarga. Dimana mereka memainkan peran relasi yang berlainan bisa berbentuk larangan dan hukuman, seperti di Minangkabau, limpapeh rumah nan gadang (tiang rumah besar, amban pura, alur dan patut, budi dan sangko yang selalu harus menjadi pertimbangan dalam bersikap, dengan kata lain telah mendominasi setiap langkah yang akan diambil.

Untuk mencalonkan diri dalam politik pada saat ini akan dihadapkan dengan berbagai aturanaturan dan hambatan-hambatan yang begitu kompleks. Dengan demikian nilai-nilai egaliter yang dianut dalam masyarakat Minangkabau, dimana kedudukan perempuan dan laki-laki adalah setara bahkan lebih tinggi dari mamak dalam keluarga, suku dan kekerabatan; namun didalam menentukan pilihan politik bertindak serta mengambil sikap politik, perempuan tidak mempunyai kebebasan mutlak disebabkan oleh faktor yang telah diuraikan diatas

Dalam hal untuk mengambil tindakan politik, tulisan ini merujuk pendapat Talcott Parsons (1951:54 yang dikutip oleh Habermas, 2007:294) dalam teori struktural-fungsionalnya bahwa masyarakat bertindak didorong oleh pemahaman kultural yang diyakini, dan berdasarkan pemahaman itu, yakni nilai-nilai dan norma-norma yang berlaku sebagai tujuan dan mengikat para aktor secara intersubjektif, serta nilai-nilai dan norma itu menjadi motif (dorongan pribadi) untuk bertindak dan pembentuk karakter manusia bersama terjadinya internalisasi, dalam arti manusia dalam mengambil keputusan untuk melakukan sesuatu, norma dan nilai yang diyakini menjadi dorongan untuk bertindak.

Namun Habermas (2007:342) mengkritik teori tindakan Parsons. Menurut Habermas teori ini mengundang konflik, terutama mengenai integrasi terhadap nilai yakni agama. Seperti dikatakan Habermas, agama tidak lagi berada pada level yang sama dengan ilmu pengetahuan, teknologi, hukum dan moralitas serta seni secara struktural maupun historis, seperti dikatakan Nietzsche (Lidinillah, 2005:66), masyarakat di
Barat kini telah telah menjauhi agama bahkan telah melupakan Tuhan.

Penulis sependapat dengan Parsons yang menyatakan bahwa tindakan tersebut dapat menjadi saluran dimana nilai-nilai kultural bergeser menjadi tindakan yang didorong oleh motivasi: "sistem sosial adalah sistem tindakan yang didorong oleh motivasi yang mengatur hubungan aktor dengan sesamanya: kepribadian adalah sistem tindakan yang didorong oleh motivasi yang mengatur organisme hidup." Namun, penulis tidak sependapat dengan Habermas, karena latar belakang falsafah yang dianut masyarakat Barat berbeda dengan falsafah yang dianut masyarakat Minangkabau, dalam hal ini mengambil suatu tindakan akan selalu berintegrasi dengan nilai-nilai moral agama yang dianut.

Berbeda dengan Parsons, dalam hal mengambil tindakan politik bagi perempuan Minangkabau, dapat juga dikaji menurut pemikiran George Herbert Mead (1982:28 dalam Ritzer, 2000:344) dalam perspektif interaksionisme simbolik. Bagi Mead, pemikiran individual secara logis dan temporal didahului oleh sosialisasi. Seorang individual yang berpikir, sadar diri, secara logis tidak mungkin lepas dari kelompok sosialnya.

Pada saat ini yang terjadi pada perempuan Minangkabau adalah keadaan mental dan gerak hatinya terhadap politik telah terperangkap di ranah domestik yang diakibatkan oleh pembingkaian (framing) makna metafora dan sanjungan yang diberikan oleh adat dan masyarakatnya dimana akan sulit untuk merobahnya dikarenakan proses sosialisasi yang telah berlangsung secara turun temurun.

\section{Penutup}

Dari uraian di atas dapat disimpulkan bahwa makna kata dalam metafora yang dibingkai dalam berbagai kata-kata terkait erat dengan proses pembingkaian makna dari kalimat-kalimat bernada sanjungan yang terdapat dalam metafor masyarakat Minangkabau. Proses sosialisasi, eksternalisasi, internalisasi objektivasi, dipengaruhi oleh kekuasaan makna kata yang terdapat dalam lembaga sosial yang pada akhirnya menyebabkan terbentuknya mindset perempuan terhadap politik menjadi lemah, dan hal ini membuat motivasi politik mereka menjadi lemah pula. Sesuai dengan teori mindnya "Mead" dan teori struktur dari, dorongan sosial yang dapat membuat motivasi menjadi tinggi tidak cukup karena selama ini sistem kemasyarakatan yang dianut adalah semua urusan politik dan urusan publik diurus oleh laki-laki, sementara 
beban kultural yang ditanggung perempuan sangat berat. Kenyataan ini tercermin dalam makna metafora masyarakat Minangkabau. Mereka tampak menyanjung perempuan dalam hal adat atau tradisi, tapi di sisi lain mereka sebenarnya menekan perempuan untuk menjauhi panggung politik sebab yang mencakup urusan publik hanya milik kaum lelaki. Ini artinya, bahasa metafor yang bernada sanjungan, pada hakikatnya hanya sebuah jebakan bagi perempuan untuk tidak berpolitik praktis.

\section{DAFTAR PUSTAKA}

Abdullah, Taufik. 1987. Sejarah dan Masyarakat: Lintasan Historis Islam di Indonesia. Terjemahan Mien Joebhar. Jakarta: Yayasan Obor Indonesia.

Al-Fayyadl, Muhammad. 2005. Derrida, Yogyakarta: LKiS.

Berger, Peter L. 1991. Kabar Angin Dari Langit; Makna Teologi dalam Masyarakat Modern, Jakarta: LP3ES.

Bustan, Fransiskus dan Ola, Simon Sabon. 2010. Guratan makna sosial dan religius lagu ongko koe dalam Guyub Tutur Manggarai di Flores dalam Journal Humaniora. Yogyakarta: Fakultas Ilmu BudayaUniversitas Gadjah Mada.

Denzin, Norman K and Yvonna S. Lincoln (Eds.). 1994. Handbooks of Qualitative Research, London: Sage.

Foucault, Michel. 2002. Power/Knowledge; Selected Interviews and Other Writings, New York: Pantheon Books.

Habermas, Jürgen. 2007. Teori Tindakan Komunikatif II: Kritik atas Rasio Fungsionalis, Yogyakarta: Kreasi Wacana.

Hiilamo and Kangas. 2005. Trap for women or freedom to choose? Political frames in the making of child home care allowance in Finland and Sweden. http://www.northwestern.edu/rc19/ Hiilamo_Kangas.pdf.

Idris, Nurwani. 2007. Perempuan Minangkabau dalam Politik (Studi tentang hambatan dan usaha untuk mendapatkan kedudukan kepemimpinan politik). Disertasi Program Doktor Program Studi Ilmu Sosial Universitas Airlangga Surabaya.

Johnson, Barbara. 2004. Translator's Introduction in Derrida, Jaques. 1981. Chicago: University of Chicago Press. http://books. google.co.id

Lechte, John. 2001. 50 Filsuf Kontemporer: Dari Strukturalisme sampai Posmodernitas. Terjemahan. A. Gunawan Admiranto. Yogyakarta: Kanisius dalam Community, Averroes. 2008. Menelusuri Jejak Pemikiran Derrida. http://www.averroes.or.id/thought/menelusuri-jejak-pemikiran-derrida.html

Lidinillah, Mustofa Anshori. 2005. Agama dan Aktualisasi Diri, Perspektif Filsafat Muhammad Iqbal, Yogyakarta: Badan Penerbit Filsafat UGM.

Naim, Mochtar. 1991. Kedudukan Wanita Minangkabau Dulu, Sekarang dan akan Datang, Disampaikan pada Simposium Nasional "Wanita di mata hukum dan kenyataan dalam masyarakat". Padang: Kerjasama PP Persahi dan Universitas Ekasakti.

Navis, AA. 1999. Yang Berjalan Sepanjang Jalan, Kumpulan Karangan Pilihan. Jakarta: Grasindo.

Navis, AA. 1984. Alam Takambang Jadi Guru: Adat dan Kebudayaan Minangkabau. Jakarta: Grafiti Press.

Parsons. 1951. Toward a General Theory of Action. New York.

Ritzer, George. 2000. Sociological Theory, Fifth Edition. New York: McGraw-Hill International Editions.

Rusbiantoro, Dadang. 2001. Bahasa Dekonstruksi ala Foucault dan Derrida. Yogyakarta: PT. Tiara Wacana, 2001.

Said, Nur. 2005. Perempuan dalam Himpitan Teologi dan HAM di Indonesia. Yogyakarta: Media Pilar. 
Tanner, Nancy. 1967. Disputing and Dispute Settlement Among the Minangkabau of Indonesia. Research. University of California, 1967.

Wattimena, Reza AA. 2009. Rumah Filsafat (The House of Philosophy): Metode Dekonstruksi Jacques Derrida. http://rezaantonius.multiply.com/journal/item/245. 